\title{
COMPARATIVE EVALUATION OF DIFFERENT POTENTIAL EVAPOTRANSPIRATION ESTIMATION APPROACHES
}

\author{
Bhaskar R. Nikam ${ }^{1}$, Pradeep Kumar², Vaibhav Garg ${ }^{3}$, Praveen K. Thakur ${ }^{4}$ and S. P. Aggarwal \\ ${ }^{1}$ Scientist/Engineer 'SD', Water Resources Department, Indian Institute of Remote Sensing, Dehradun, Uttarakhand, India \\ ${ }^{2}$ Scientist ' $B$ ', Jammu Regional Centre, National Institute of Hydrology, Jammu, J\&K, India \\ ${ }^{3}$ Scientist/Engineer 'SD', Water Resources Department, Indian Institute of Remote Sensing, Dehradun, Uttarakhand, India \\ ${ }^{4}$ Scientist/Engineer 'SE', Water Resources Department, Indian Institute of Remote Sensing, Dehradun, Uttarakhand, India \\ ${ }^{5}$ Head, Water Resources Department, Indian Institute of Remote Sensing, Dehradun, Uttarakhand, India
}

\begin{abstract}
Accurate estimation of potential evapotranspiration is necessary step in water resources management. Recently, the FAO-56 version of Penman-Monteith equation has been established as a standard for calculating reference evapotranspiration (ET $T_{0}$ ). Still there are different approaches (requiring less data) which estimate ET $T_{0}$ closely to Penman-Monteith method for different climatological conditions. Performance Evaluation of all the approaches on the same basis is prerequisite for selecting an alternative approach in accordance with available data. Therefore, two most popular temperature-based approaches (Hargreaves and Thornthwaite) and two radiation based approaches (Priestley-Taylor and Turc) were used to estimate monthly potential evapotranspiration (ET $)$ at Pantnagar (Uttarakhand), India. Further, the performance of all these methods were evaluated by regression and error analysis between standard ET $T_{0}$ derived using FAO-56 Penman-Monteith method and ET $T_{0}$ values estimated using all the four methods, on monthly and seasonal basis. On monthly basis Turc method performed best with lowest RMSE (0.562), ARE (0.137), AAD (0.448) and high coefficient of determination (0.792). On seasonal basis, the Priestley-Taylor methodwas found to be the best for Rabiseasonwith lowest error values and minimum seasonal over/under ET $T_{0}$ predication rate with respect to standard ET. Turc method holds second rank in Rabi season. However in Kharif season Truc method performed better than any other method with lowest error terms and lowest seasonal over/under predication rate. In summer season all the methods performed poorly compared to other two seasons but Hargreaves method performed better than other methods. Though the performance and accuracy of FAO-56 Penman-Monteith method can never be debated in theoretical or practical applications yet the comparative evaluation performed in this paper can be used as guideline for selection of alternative or less data dependent methods in case of non-availability of data.
\end{abstract}

Keywords:Potential Evapotranspiration, FAO-56 Penman-Monteith method, Hargreaves method, Turc method, Priestley-Taylor method.

\section{INTRODUCTION}

Evapotranspiration (ET) is one of the major components of the hydrologic cycle. Around $64 \%$ of landbased average annual precipitation returns back to atmosphere due to process of evaporation $[8,31,22]$. Evapotranspiration not only plays major role in global water balance but also significantly influence the global energy balance. Hence, quantification of evapotranspiration is necessary for water resources management, irrigation scheduling and environmental assessment [14]. A general procedure for estimating actual evapotranspiration $\left(\mathrm{ET}_{\mathrm{a}}\right)$ is to first estimate potential evapotranspiration $\left(\mathrm{ET}_{0}\right)$. Further, crop coefficients, which depend on the crop characteristics and local conditions, are used to convert $\mathrm{ET}_{0}$ to the $\mathrm{ET}_{\mathrm{a}}$. Allen et al.[1] defined $\mathrm{ET}_{0}$ as "the rate of evapotranspiration from a hypothetical crop with an assumed crop height $(0.12 \mathrm{~m})$ and a fixed canopy resistance $(70 \mathrm{~s} / \mathrm{m})$ and albedo $(0.23)$ which would closely resemble evapotranspiration from an extensive surface of green grass cover of uniform height, actively growing, completely shading the ground and not short of water." There are numerous methods available in literature for estimation of potential evapotranspiration $\left(\mathrm{ET}_{0}\right)$, these methods are generally classified as temperaturebased,radiation-based, pan evaporation-based or combination type methods based on type of data required $[26,37,38,21]$.

The comparative evaluation of these methods is done by several researchers $[5,19,2,35,39,13,26,37,38]$ in varying climatic conditions worldwide. In Indian context earlier studies suggested FAO-24 [7] method as most accurate one $[29,18]$. However, attempts were also made by researchers to find out less data demanding and simpler methods for few locations in India [20]. Mohan [20] has recommended the FAO-24 radiation method in per-humid climates, the Hargreaves and Samani[11] temperature-based method in humid climates, and the FAO-24 Blaney-Criddle temperature-based method in subhumid and semiarid climates of Tamil Nadu, India.

Owing to its superiority tested worldwide the "physically based" combination approach of FAO-56 version of Penman-Monteith (FAO-PM) equation [1] has been 
established/accepted as a standard for calculating reference evapotranspiration $[14,36,12,13,9,17,4,3]$. Superior accuracy of FAO-56 Penman-Monteith methods is also verified in Indian conditions by Kashyap and Panda [15] over FAO-24 Penman method. Application of FAO-PM methods will certainly improve the irrigation water-use efficiencies, water balance and water distribution at project and state levels, $[13,34,21]$. However, use of FAO-PM method is constrained by non-availability of detailed meteorological data (especially the radiation, wind velocity and relative humidity) even in developed countries [9] and at majority of locations in developing country [22]. The better performance of temperature and radiation based approach with observed radiation data over FAO-56 PM methods with estimated radiation data is evident [22]. Therefore by the time dense network of advance meteorological observatories (automatic weather stations) is established in the country, simpler and less data demanding evapotranspiration estimation techniques will be widely preferred by researchers and water resources professionals. Hence, there is an urgent need to re-evaluate the performances of simpler $\mathrm{ET}_{0}$ estimation methods with reference to the FAO-56 PM method under different climatic conditions most commonly encountered in India [21].

So, the basic goal of this paper is to evaluate the comparative performance of most popular Temperaturebased approaches; Hargreaves method [11] and Thornthwaite method [32], Radiation based approaches; Priestley-Taylor method [25], and Turc method [33] with standard $\mathrm{ET}_{0}$ derived using FAO-56 Penman-Monteith method [1], on monthly and seasonal basis.

\section{STUDY AREA}

Monthly weather data from meteorological observatory of G. B. Pant University of Agriculture and Technology, Pantnagar have been used for estimating and analyzing the $\mathrm{ET}_{0}$ using different methods. The site is located in the Terai belt at the foothills of Shivalik range of the Himalayas. Its geographical location is $29.50^{\circ} \mathrm{N}$ latitude and $79.30^{\circ} \mathrm{E}$ longitude. Pantnagar has an altitude of $243.8 \mathrm{~m}$ above mean sea level. It has humid, sub-tropic climate. The summer is too dry and hot, the winter is too cold and the rainy season has a heavy rainfall. The hygrometer shows upto $90 \%$ relative humidity during winter and upto $55 \%$ during summer at 7.00 AM. The monthly mean of maximum temperature lies in the range of $20^{\circ} \mathrm{C}$ to $40^{\circ} \mathrm{C}$. The minimum temperature varies between $5^{\circ} \mathrm{C}$ to $25^{\circ} \mathrm{C}$. May is the hottest and January is the coolest month. The monsoon season experiences about $90 \%$ of the average annual rainfall of about $148.3 \mathrm{~cm}$.

\section{METHODOLOGY}

\subsection{Data and Methods}

Monthly meteorological data of maximum and minimum temperature, relative humidity, wind velocity at $2 \mathrm{~m}$ height and sunshine hours were available from meteorological observatory in the campus of G.B. Pant University of Agriculture and Technology, Pantnagar, Uttarakhand, India for the time period from January, 1991 to December, 2000. The monthly weather data was used to estimate the monthly $\mathrm{ET}_{0}(\mathrm{~mm} /$ day). The average monthly values of weather data over this period are given in Table 1 .

Table 1: Average monthly and annual weather data

\begin{tabular}{|c|c|c|c|c|c|c|}
\hline \multirow[b]{3}{*}{ Month } & \multicolumn{2}{|c|}{ Temperature } & \multicolumn{2}{|c|}{$\begin{array}{l}\text { Relative } \\
\text { Humidity }\end{array}$} & \multirow{2}{*}{$\begin{array}{l}\text { Wind } \\
\text { velocity }\end{array}$} & \multirow{2}{*}{$\begin{array}{l}\text { Sunshine } \\
\text { hours }\end{array}$} \\
\hline & $\min$ & $\max$ & $\min$ & $\max$ & & \\
\hline & $\left({ }^{\circ} \mathrm{C}\right)$ & $\left({ }^{\circ} \mathrm{C}\right)$ & $(\%)$ & $(\%)$ & $(\mathrm{km} / \mathrm{h})$ & h \\
\hline Jan & 06.23 & 19.50 & 56.76 & 93.04 & 3.77 & 5.63 \\
\hline Feb & 08.25 & 23.00 & 48.37 & 90.89 & 4.15 & 7.24 \\
\hline Mar & 11.63 & 27.95 & 38.71 & 86.87 & 5.29 & 8.20 \\
\hline Apr & 16.69 & 34.97 & 25.24 & 69.13 & 5.97 & 9.50 \\
\hline May & 22.19 & 37.66 & 31.37 & 62.39 & 7.69 & 9.60 \\
\hline Jun & 25.03 & 36.26 & 48.69 & 74.06 & 7.93 & 8.03 \\
\hline Jul & 25.42 & 32.90 & 68.86 & 88.87 & 5.85 & 5.93 \\
\hline Aug & 24.99 & 31.77 & 73.89 & 92.16 & 4.83 & 5.20 \\
\hline Sep & 23.29 & 31.73 & 67.61 & 91.96 & 3.20 & 6.88 \\
\hline Oct & 17.39 & 30.92 & 49.55 & 86.89 & 2.30 & 8.63 \\
\hline Nov & 11.20 & 27.33 & 44.50 & 89.42 & 2.04 & 8.30 \\
\hline Dec & 07.02 & 22.77 & 48.66 & 93.02 & 2.15 & 6.85 \\
\hline Average & 16.61 & 29.73 & 50.18 & 84.89 & 4.60 & 7.50 \\
\hline
\end{tabular}

On the basis of available data, the methods selected for estimation of $\mathrm{ET}_{0}$ were categorized into (i) Temperature based methods:- Hargreaves method (HS) and Thornthwaite method (TH), (ii) Radiation based methods:- PriestleyTaylor method (PT), and Turc method (TC). As per the recommendations FAO expert consultation Panel [28] the $\mathrm{ET}_{0}$ estimated using FAO-56 Penman-Monteith method should be taken as standard $\mathrm{ET}_{0}$ for comparative evaluation of other ET estimation methods so, FAO-56 PenmanMonteith method [1] was used to estimating $\mathrm{ET}_{0}$ as standard for comparison of results of other four methods listed above. The potential evapotranspiration $\left(\mathrm{ET}_{0}\right)$ estimated using FAO-56 Penman-Monteith (FAO-PM) method will be termed as standard $\mathrm{ET}_{0}$ hereafter. All the five methods used to estimate $\mathrm{ET}_{0}$ in this paper are briefly described here:

\subsubsection{Temperature Based Methods}

1) Hargreaves Method:-The Hargreaves method [11, 10] enables reference crop evapotranspiration $\left(\mathrm{ET}_{0}\right)$ estimation in areas where meteorological information is scarce. This is an empirical estimation method that uses the average daily air temperature, $\mathrm{T}\left({ }^{\circ} \mathrm{C}\right)$, in combination with the extraterrestrial radiation, $\mathrm{R}_{\mathrm{a}}\left(\mathrm{MJ} / \mathrm{m}^{2} /\right.$ day $)$ as an indicator of the incoming global radiation. The Hargreaves equation is expressed as:

$$
E T_{0}=0.0023 R_{a}\left(\frac{T_{\max }+T_{\min }}{2}+17.8\right) \sqrt{T_{\text {max }}-T_{\min }}
$$


Where, $T_{\max }$ and $T_{\min }$ are average maximum and minimum temperatures.

2) ThornthwaiteMethod:-Thornthwaite [32] correlated mean monthly temperature with ET as determined by eastcentral United States water balance studies. The Thornthwaite equation is:

$$
E T_{0 k}=\frac{16 N_{k}}{360}\left(\frac{10 T_{k}}{\sum_{k=1}^{12}\left(0.2 T_{k}\right)^{1.514}}\right)^{0.016 \sum_{k=1}^{12}\left(0.2 T_{k}\right)^{1.514}+0.5}
$$

Where, $E T_{0 k}$ is potential evapotranspiration in the $\mathrm{k}^{\text {th }}$ month (mm); $N_{k}$ is the maximum possible duration of sunshine in the $\mathrm{k}^{\text {th }}$ month (hours); $T_{k}$ is the mean air temperature in the $\mathrm{k}^{\text {th }}$ month $\left({ }^{\circ} \mathrm{C}\right)$ and $k=1,2, \ldots . ., 12$.

\subsubsection{Radiation Based Methods}

1) TurcMethod:-Turc[33] developed an equation for potential ET under general climatic conditions of Western Europe. He proposed the following equations for two humidity conditions:

When $R H_{\text {mean }}>50 \%$,

$$
E T_{0}=0.013 \frac{T_{\text {mean }}}{\left(T_{\text {mean }}+15\right)}\left(R_{s}^{\prime}+50\right) \frac{1}{\lambda}
$$

When $R H_{\text {mean }} \leq 50 \%$,

$$
E T_{0}=0.013 \frac{T_{\text {mean }}}{\left(T_{\text {mean }}+15\right)}\left(R_{s}^{\prime}+50\right) \frac{1}{\lambda}\left(1+\frac{\left(50-R H_{\text {mean }}\right)}{70}\right)(4)
$$

Where, $T_{\text {mean }}$ is mean air temperature $\left({ }^{\circ} \mathrm{C}\right), R H_{\text {mean }}$ ismean relative humidity $(\%), \mathrm{R}_{\mathrm{s}}$ is solar radiation ( $\mathrm{cal} / \mathrm{cm}^{2} /$ day). If $R_{s}\left(\mathrm{MJ} / \mathrm{m}^{2} /\right.$ day $)$ is known, it can be calculated as

$$
R_{s}^{\prime}=R_{s} / 0.041869
$$

$\lambda$ is the latent heat of vaporization $(\mathrm{MJ} / \mathrm{kg})$. it can be estimated using mean air temperature as

$$
\lambda=2.501-0.002361 T_{\text {mean }}
$$

2) Priestly-Taylor Method:-Priestly and Taylor [25] proposed an equation for surface area generally wet, which is a condition, required for potential evaporation. The equation can be expressed as:

$$
E_{p}=\alpha \frac{1}{\lambda} \frac{\Delta}{(\Delta+\gamma)}\left(R_{n}-G\right)
$$

Where, $\Delta$ is slope of saturation vapor pressure-temperature curve $\left(\mathrm{kPa} /{ }^{\circ} \mathrm{C}\right)$, it can be calculated if $T_{\text {mean }}$ values are known using Teten's expression as:

$$
\Delta=\frac{4098 e_{\text {mean }}^{0}}{\left(T_{\text {mean }}+237.3\right)}
$$

Where, $e_{\text {mean }}^{0}$ is saturation vapor pressure at mean temperature $(\mathrm{kPa}), \gamma$ is Psychometric constant $\left(\mathrm{kPa} /{ }^{\circ} \mathrm{C}\right), R_{n}$ is Net Radiation $\left(\mathrm{MJ} / \mathrm{m}^{2} /\right.$ day), $\alpha$ is short wave reflectance or albedo and its value is taken as 0.23 , and $G$ is heat flux density to the ground $\left(\mathrm{MJ} / \mathrm{m}^{2} /\right.$ day $)$.

\subsubsection{Combination Method}

1) FAO Penman-MonteithMethod:-The International Commission for Irrigation and Drainage and Food and Agriculture Organisation of the United Nations has proposed the FAO Penman-Monteith method [1] as the standard method for estimating reference evapotranspiration. FAO modified Penman-Monteith method popularly known and FAO-56 PM method is expressed as:

$$
E T_{0}=\frac{0.408 \Delta\left(R_{n}-G\right)+\gamma \frac{900}{T_{\text {mean }}+273} U_{2}\left(e_{s}-e_{a}\right)}{\Delta+\gamma\left(1+0.34 U_{2}\right)}
$$

Where, $E T_{0}$ is reference evapotranspiration ( $\mathrm{mm} /$ day), $U_{2}$ is average 24 hour wind speed at $2 \mathrm{~m}$ height $(\mathrm{m} / \mathrm{s})$, and $e_{s}-e_{a}$ is saturation vapour pressure deficit $(\mathrm{kPa}), R_{n}$ is net radiation at the crop surface $\left(\mathrm{MJ} / \mathrm{m}^{2} / \mathrm{day}\right), \mathrm{G}$ is soil heat flux $\left(\mathrm{MJ} / \mathrm{m}^{2} /\right.$ day $), \Delta$ is slope of vapour pressure curve $\left(\mathrm{kPa} /{ }^{\circ} \mathrm{C}\right), \gamma$ is psychrometric constant, $e_{s}$ is saturation vapour pressure $(\mathrm{kPa}), e_{a}$ is actual vapour pressure $(\mathrm{kPa})$.

The FAO-56 Penman-Monteith (FAO-56 PM) method requires observations of maximum and minimum air temperature, maximum and minimum relative air humidity (or the actual vapour pressure), wind speed at $2 \mathrm{~m}$ height, and solar radiation for accurately estimating $\mathrm{ET}_{0}$. Where radiation data are lacking, or not reliable, the solar radiation $\left(R_{n}\right)$ can be estimated using bright sunshine hours records as suggested by Allen et al[1]

$$
R_{n}=R_{n s}-R_{n l}
$$

Where, $R_{n s}$ is net shortwave radiation $\left(\mathrm{MJ} / \mathrm{m}^{2} /\right.$ day) and $R_{n l}$ is net longwave radiation $\left(\mathrm{MJ} / \mathrm{m}^{2} /\right.$ day)

$$
R_{n s}=(1-\alpha) R_{s}
$$

Where, $R_{s}$ is incoming solar or shortwave radiation $\left(\mathrm{MJ} / \mathrm{m}^{2} /\right.$ day) and $\alpha$ albedo or canopy reflectance coefficient $(\alpha=0.23$, for hypothetical grass reference surface). 


$$
R_{s}=a_{s}+b_{s} \frac{n}{N} R_{a}
$$

Where, $R_{a}$ is extraterrestrial radiation $\left(\mathrm{MJ} / \mathrm{m}^{2} / \mathrm{day}\right), \mathrm{n}$ is actual duration of sunshine (hours), $\mathrm{N}$ is maximum possible duration of sunshine, $a_{s}$ is regression constant expressing the fraction of extraterrestrial radiation that will reach the earth surface on overcast/cloudy days $(n=0)$ and $a_{s}+b_{s}$ is fraction of extraterrestrial radiation that reaches earth surface on clear sky days $(n=N)$

$$
\begin{gathered}
R_{a}=\frac{1440}{\pi} G_{s} d_{r}\left[\omega_{s} \sin (\phi) \sin (\delta)+\sin \left(\omega_{s}\right) \cos (\phi) \cos (\delta)\right] \\
d_{r}=1+0.033 \cos \left(\frac{2 \pi}{365} J\right) \\
\delta=0.409 \sin \left(\frac{2 \pi}{365} J-1.39\right) \\
\omega_{s}=\arccos [-\tan (\phi) \tan (\delta)]
\end{gathered}
$$

Where, $G_{s}$ is solar constant $\left(0.0820 \mathrm{MJ} / \mathrm{m}^{2} /\right.$ day $), d_{r}$ inverse relative Earth-Sun distance, $\omega_{s}$ is sunset hour angle $(\mathrm{rad}), \delta$ is solar declination angle (rad) and $\Phi$ is latitude of station $(\mathrm{rad}), J$ is the number of the day in calendar year.

$$
R_{n l}=\sigma\left[\frac{T_{\max , K}^{4}-T_{\min , K}^{4}}{2}\right]\left(0.34-0.14 \sqrt{e_{a}}\right)\left(1.35 \frac{R_{s}}{R_{s o}}-0.35\right)
$$

Where, $\sigma$ is Stefan-Boltzman constant $\left(4.903 \times 10^{-9}\right.$ $\mathrm{MJ} / \mathrm{K}^{4} / \mathrm{m}^{2} /$ day), $T_{\max , K} \& T_{\min , K}$ are absolute maximum and minimum temperature values $\left({ }^{0} \mathrm{~K}\right)$, ratio $R_{s} / R_{s o}$ is relative shortwave radiation (limited to $\leq 1.0$ ) and $R_{s o}$ is clear sky radiation $\left(\mathrm{MJ} / \mathrm{m}^{2} /\right.$ day) estimated as;

$$
R_{s o}=\left(a_{s}+b_{s}\right) R_{a}
$$

The data requirement of all these methods are summarized in Table 2.

A program in Microsoft Visual Basic (VB 6.0) language was developed to calculate $\mathrm{ET}_{0}$ from five methods mentioned above. The height of the reference crop was chosen as $12 \mathrm{~cm}$ with a fixed canopy resistance of $70 \mathrm{sec} / \mathrm{m}$, and albedo as 0.23 to resemble ET from an extensive surface

\begin{tabular}{|c|c|c|c|c|c|}
\hline $\begin{array}{l}\text { Methods } \\
\text { Data }\end{array}$ & FAO-PM & PT & TC & $\mathrm{TH}$ & HS \\
\hline $\begin{array}{l}\text { Max. and } \min \\
\text { temperature }\end{array}$ & $\sqrt{ }$ & $\checkmark$ & $\checkmark$ & $\vee^{2}$ & $\checkmark$ \\
\hline $\begin{array}{l}\text { Average } \\
\text { temperature }\end{array}$ & $\sqrt{ }^{2}$ & $\sqrt{ }^{2}$ & $\sqrt{ }^{2}$ & $\checkmark$ & $\sqrt{ }^{2}$ \\
\hline $\begin{array}{l}\text { Max. and min. } \\
\text { RH }\end{array}$ & $\checkmark$ & $\checkmark$ & $\checkmark$ & - & - \\
\hline $\begin{array}{l}\text { Average } \\
\text { relative } \\
\text { humidity }\end{array}$ & $\sqrt{ }^{2}$ & $\sqrt{ }^{2}$ & $\sqrt{ }^{2}$ & - & - \\
\hline $\begin{array}{l}\text { Avg. } \\
\text { speed }\end{array}$ & $\mathrm{d}{ }_{\checkmark}$ & $\checkmark$ & - & |- & - \\
\hline Sunshine hours & $\sqrt{ }$ & $\checkmark$ & $\checkmark^{*}$ & - & - \\
\hline Solar radiation & $\checkmark^{*}$ & $\checkmark^{*}$ & $V^{*}$ & - & - \\
\hline Net radiation & $\checkmark^{*}$ & $\checkmark^{*}$ & $\checkmark^{*}$ & - & - \\
\hline Other data & \begin{tabular}{|l} 
Latitude \\
Elevation \\
Julian day
\end{tabular} & \begin{tabular}{|l|} 
Latitude \\
Elevation \\
Julian day
\end{tabular} & \begin{tabular}{|l} 
Latitude \\
Elevation \\
Julian day
\end{tabular} & $\begin{array}{l}\text { Latitude } \\
\text { Julian } \\
\text { day }\end{array}$ & $\begin{array}{l}\text { Latitude } \\
\text { Julian } \\
\text { day }\end{array}$ \\
\hline $\begin{array}{l}\text { Note: i) sign } \\
\text { having supers } \\
\text { from primary }\end{array}$ & $\checkmark$ indica & that the & lata is $e$ & sential, & ii) Data \\
\hline
\end{tabular}
of actively growing green grass of uniform height, completely shading the ground and not short of water. Values of monthly $\mathrm{ET}_{0}(\mathrm{~mm} /$ day) were estimated using this program. Monthly values were then used to calculate seasonal (Rabi, Kharif and Summer) $\mathrm{ET}_{0}$ values.
Table 2: Data requirements of estimation methods

\subsection{Evaluation Criteria}

The regressions analysis was done to examine the performance of four methods compared with the standard $\mathrm{ET}_{0}$ on monthly and seasonal basis. The regression equations computed is of the form:

$$
Y=m X+C
$$

Where, Y represents estimated monthly $\mathrm{ET}_{0}$ (mm/day); Xis standard $\mathrm{ET}_{0}$ from each of the four methods (mm/day); and mand $\mathrm{C}$ are slope and intercept, respectively. Care was taken to force the regressions lines to have intercept zero for all the cases [22].

Further, statistical error analysis was carried out with the parameters; root mean square error (RMSE), absolute average deviation (AAD) and absolute relative error (ARE) $[9,22]$.

$$
\begin{aligned}
& R M S E=\sqrt{\frac{\sum_{i=1}^{n}\left(y_{i}-x_{i}\right)}{n}} \\
& A A D=\frac{\sum_{i=1}^{n} A B S\left(y_{i}-x_{i}\right)}{n} \\
& A R E=\frac{A B S\left(y_{i}-x_{i}\right)}{x_{i}}
\end{aligned}
$$

Where, $y_{i}$ is estimated and $x_{i}$ is standard $\mathrm{ET}_{0}$. The RMSE parameter has been used to indicate the 
goodness-of-fit of $\mathrm{ET}_{0}$ estimates. The best method is the one with the lowest absolute average deviation, mvalue closest to 1.0 , the smallest RMSE, and the highest $\mathrm{R}^{2}[23,24]$. The difference in $\mathrm{ET}_{0}$ rates with respect to standard $\mathrm{ET}_{0}$ was also estimated and termed as over/under prediction rate of particular methods on both monthly and average seasonal time scale. The comparative evaluation of methods was performed on monthly and seasonal time scale using regression analysis $\left(\mathrm{R}^{2}, \mathrm{~m}\right)$ and error analysis (RMSE, AAD, ARE, over/under predication rate).

\section{RESULTS}

The monthly $\mathrm{ET}_{0}$ values estimated by each of the five methods for the period of record used in present study are shown in Fig. 1 and their mean values are given in Table 3. Results obtained from the regression of $\mathrm{ET}_{0}$ estimated by each of the four methods against standard $\mathrm{ET}_{0}$ (derived using FAO-PM method) on monthly basis and seasonal basis are presented in Table 4 and Table 5 respectively.

Table 3: Standard and estimated mean monthly $\mathrm{ET}_{0}$ (mm/day) and total annual $\mathrm{ET}_{0}(\mathrm{~mm})$.

\begin{tabular}{|l|l|l|l|l|l|}
\hline Month & Standard & HS & TH & TC & PT \\
\hline Jan & 1.518 & 2.15 & 0.5 & 1.84 & 1.41 \\
\hline Feb & 2.085 & 2.73 & 0.94 & 2.54 & 1.89 \\
\hline Mar & 3.304 & 4.03 & 1.97 & 3.48 & 2.92 \\
\hline Apr & 5.250 & 5.89 & 4.56 & 5.02 & 4.26 \\
\hline May & 6.592 & 6.79 & 7.36 & 5.74 & 5.41 \\
\hline Jun & 6.024 & 6.32 & 8.08 & 5.06 & 5.75 \\
\hline Jul & 4.535 & 5.1 & 6.93 & 4.34 & 5.26 \\
\hline Aug & 3.951 & 4.51 & 6.08 & 3.99 & 4.78 \\
\hline Sep & 4.003 & 4.47 & 5.19 & 4.2 & 4.8 \\
\hline Oct & 3.627 & 4.43 & 3.3 & 4.03 & 4.12 \\
\hline Nov & 2.554 & 3.55 & 1.62 & 3.1 & 2.76 \\
\hline Dec & 1.714 & 2.78 & 0.74 & 2.21 & 1.76 \\
\hline Annual & 1375.78 & 1582.32 & 1417.88 & 1365.63 & 1354.05 \\
\hline
\end{tabular}

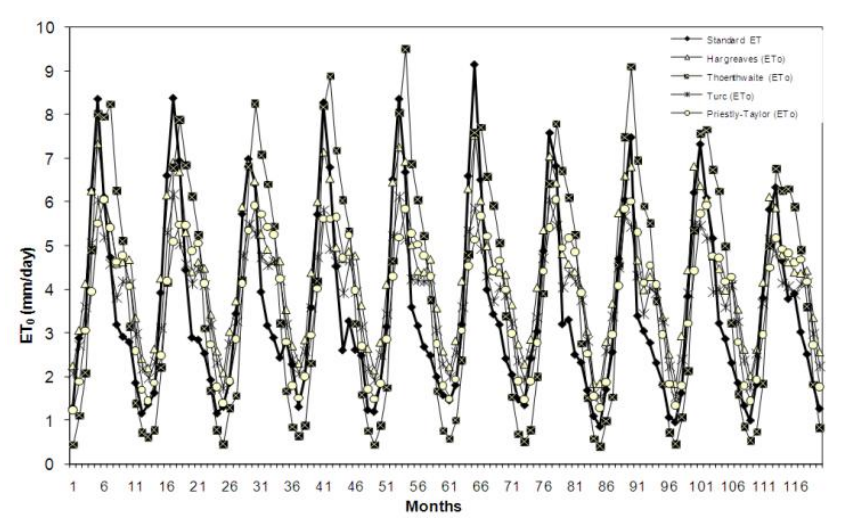

Fig. 1Estimated and standard monthly $\mathrm{ET}_{0}$.

\subsection{Monthly Basis}

The comparative evaluation of error and regression analysis results indicates that the TC method performed best with the lowest RMSE (0.562), lowest AAD (0.448), second lowest
AAR (0.137) and the high coefficient of determination $\left(\mathrm{R}^{2}=\right.$ 0.792)for monthly $\mathrm{ET}_{0}$ predictions. HS method was found to be closely following the TC method owing to low RMSE (0.704) highest coefficient of determination $\left(R^{2}=0.792\right)$ values as shown in Table 4 . Though the $\mathrm{R}^{2}$ values of HS are higher than TC method, since coefficient of determination $\left(\mathrm{R}^{2}\right)$ in linear regression is only an indicator of how well the regression line fits with original data and do not consider the actual closeness/error of each estimated record with respect to actual/standard record [6], more weightage is given to the results of error analysis in present study.It is evident from Table 4 that PT method also closely follows HS method with reference to error analysis results however, the second rank has been given to HS method owing to it's minimal data requirement compared to the extensive data requirement of PT method (almost equivalent to FAO PM method).

\subsection{Seasonal Basis}

The regression analysis between monthly $\mathrm{ET}_{0}$ estimates of each of the method and standard $\mathrm{ET}_{0}$ was done for three seasons (Rabi: November to March; Summer: April to June and Kharif: July to October) to evaluate performance of each of the technique. The definition of time frame of each season is based on standard agricultural practice followed in the region. The trend of predicting/estimating $\mathrm{ET}_{0}$ by each technique is derived by comparing the $\mathrm{ET}_{0}$ estimates with standard $\mathrm{ET}_{0}$ values and numerated in the form of slope of trend line and coefficient of determination $\left(\mathrm{R}^{2}\right)$ in Table 5 .

Table 4:Summary statistics of regression and error

(mm/day) analysis between standard and estimated $\mathrm{ET}_{0}$

\begin{tabular}{|l|l|l|l|l|l|}
\hline & $\begin{array}{l}\text { Regression } \\
\text { equation }\end{array}$ & $\mathrm{R}^{2}$ & RMSE & AAD & ARE \\
\hline $\begin{array}{l}\text { Hargreaves- } \\
\text { Samani(HS) }\end{array}$ & $\mathrm{Y}=1.1224 * \mathrm{X}$ & 0.889 & 0.704 & 0.632 & 0.223 \\
\hline $\begin{array}{l}\text { Thornthwaite } \\
(\mathrm{TH})\end{array}$ & $\mathrm{Y}=1.1173 * \mathrm{X}$ & 0.752 & 1.424 & 1.260 & 0.387 \\
\hline Turc (TC) & $\mathrm{Y}=0.9607 * \mathrm{X}$ & 0.792 & 0.562 & 0.448 & 0.137 \\
\hline $\begin{array}{l}\text { Priestly- } \\
\text { Taylor (PT) }\end{array}$ & $\mathrm{Y}=0.9722 * \mathrm{X}$ & 0.771 & 0.724 & 0.550 & 0.133 \\
\hline
\end{tabular}

Table 5: Regression analysis between monthly values of standard and estimated $\mathrm{ET}_{0}$ for three seasons

\begin{tabular}{|c|c|c|c|c|c|c|c|c|}
\hline \multirow[b]{2}{*}{ Season } & \multicolumn{2}{|l|}{ HS } & \multicolumn{2}{|l|}{ TH } & \multicolumn{2}{|l|}{ TC } & \multicolumn{2}{|l|}{ PT } \\
\hline & m & $\mathbf{R}^{2}$ & $\mathbf{m}$ & $\overline{\mathbf{R}^{2}}$ & $\mathbf{m}$ & $\mathbf{R}^{2}$ & m & $\overline{R^{2}}$ \\
\hline Rabi & 1.322 & 0.857 & 0.538 & 0.769 & 1.156 & 0.775 & 0.956 & 0.796 \\
\hline Kharif & 1.135 & 0.652 & 1.335 & 0.560 & 1.024 & 0.658 & 1.173 & 0.915 \\
\hline Sumı & 1.068 & 0.128 & 1.124 & 0.467 & 0.876 & -0.11 & 0.855 & 0.046 \\
\hline
\end{tabular}

It is not possible to evaluate the overall performance of any method based on single parameter (i.e. coefficient of determination) because judging the accuracy of these methods is not simple task. Even experimentally observed data have limitations due to the difficulties of simulating the ideal conditions as defined for $\mathrm{ET}_{0}$. Therefore, as suggested 
by Kumar et al.[16] the physical and dynamical nature of these methods, which will be reflected by closeness of estimates with standard $\mathrm{ET}_{0}$ values has to be taken as a basis for evaluating the relative merits of each of the technique. Hence the results of error analysis as shown in Table 6 were also considered for comparative evaluation of these methods.

Table 6: Error (mm/day) analysis between values of standard and estimated $\mathrm{ET}_{0}$ for three seasons

\begin{tabular}{|c|c|c|c|c|c|c|}
\hline \multirow[b]{2}{*}{ Season } & \multicolumn{3}{|l|}{ HS } & \multicolumn{3}{|l|}{ TH } \\
\hline & RMSE & AAD & ARE & RMSE & $\mathrm{AAD}$ & ARE \\
\hline Rabi & 0.796 & 0.768 & 0.369 & 1.106 & 1.077 & 0.512 \\
\hline Kharif & 0.608 & 0.563 & 0.153 & 1.708 & 1.492 & 0.373 \\
\hline \multirow[t]{2}{*}{ Summer } & 0.688 & 0.522 & 0.097 & 1.420 & 1.205 & 0.203 \\
\hline & \multicolumn{3}{|l|}{ TC } & \multicolumn{3}{|l|}{ PT } \\
\hline Season & RMSE & AAD & ARE & RMSE & $\mathrm{AAD}$ & ARE \\
\hline Rabi & 0.469 & 0.434 & 0.212 & 0.287 & 0.204 & 0.084 \\
\hline Kharif & 0.277 & 0.226 & 0.061 & 0.721 & 0.683 & 0.172 \\
\hline Summer & 0.904 & 0.797 & 0.128 & 1.105 & 0.895 & 0.145 \\
\hline
\end{tabular}

On the basis of errors in estimating $\mathrm{ET}_{0}$ in Rabi season, the PT method performed better over all other methods with lowest RMSE values (0.287) as shown in Table 6. Though the $\mathrm{R}^{2}$ value of $\mathrm{HS}$ was highest $(0.857)$ in Rabi season however, the difference in $\mathrm{R}^{2}$ values between PT and HS is practically insignificant.

The seasonal over/under predication rate of $\mathrm{ET}_{0}(\mathrm{~mm} /$ day $)$ shown in Table 7 indicates that PT predicts $\mathrm{ET}_{0}$ most closely to FAO-PM method. So in Rabi season PT holds the rank of best method among all four method for estimating potential evapotranspiration $\left(\mathrm{ET}_{0}\right)$. However, the data requirement of PT method is similar to FAO-PM method hence the accuracy obtained by this method do not have any practical significance in data non-availability scenario. On the other hand, less data demanding TC methods holds second rank in Rabi season based on error analysis (RMSE $=0.469)$ and seasonal over/under predication rates $(+0.397)$. In Kharif season TC method performs better than all other methods with lowest RMSE (0.277) lowest AAD (0.226) and lowest seasonal over/under $\mathrm{ET}_{0}$ estimation rate (0.108). Though $\mathrm{R}^{2}$ value of $\mathrm{PT}$ in Kharif is highest as shown in Table 5, but the deviations in $\mathrm{ET}_{0}$ estimated using PT from standard $\mathrm{ET}_{0}$ (FAO-PM) values are more compared to deviations between standard $\mathrm{ET}_{0}$ and estimates of $\mathrm{TC}$ method as evident form AAD values of TC and PT in Kharif season ( 0.226 and 0.683 respectively) shown in Table 6 . This indicates that $\mathrm{TC}$ estimates $\mathrm{ET}_{0}$ values more close to standard $\mathrm{ET}_{0}$ values and hence $\mathrm{TC}$ is the best method in Kharif season for estimating $\mathrm{ET}_{0}$ compared with reference to FAO-PM method results (standard $\mathrm{ET}_{0}$ ).

In case of summer season the $\mathrm{R}^{2}$ value of all the methods are low hence no inference can be drawn from these values but the analysis of errors and over/under prediction rates in this season indicates that HS method performers well compared to all other methods with average $0.375 \mathrm{~mm} /$ day over predication of $\mathrm{ET}_{0}$ and lowest RMSE (0.688). It is observed that the rate of over predication and values of RMSE in summer season are high in case of all the methods. This may be due to extreme hot and dry climate of the Pantnagar station in summer months. However the performance of HS method in Summer season is appreciable as compared to all other (radiation and combination based) methods as it utilizes very small amount of meteorological data and provide fairly accurate results of $\mathrm{ET}_{0}$.

Table 7: Over/under estimates of $\mathrm{ET}_{0}$ ( $\mathrm{mm} /$ day) for different seasons.

\begin{tabular}{|c|c|c|c|c|c|}
\hline \multirow[b]{2}{*}{ Season } & \multirow[b]{2}{*}{ Month } & \multicolumn{2}{|l|}{ HS } & \multicolumn{2}{|l|}{ TH } \\
\hline & & Over & Under & Over & Under \\
\hline \multirow{7}{*}{$\begin{array}{l}\tilde{\tilde{a}} \\
\underline{\underline{u}}\end{array}$} & Nov & 0.991 & - & - & 0.937 \\
\hline & Dec & 1.065 & - & - & 0.972 \\
\hline & Jan & 0.636 & - & - & 1.019 \\
\hline & Feb & 0.645 & - & - & 1.148 \\
\hline & Mar & 0.726 & - & - & 1.338 \\
\hline & Seasonal & \multicolumn{2}{|l|}{+0.813} & \multicolumn{2}{|l|}{-1.083} \\
\hline & & & & & \\
\hline \multirow{5}{*}{ 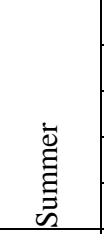 } & Apr & 0.638 & - & - & 0.692 \\
\hline & May & 0.195 & - & 0.764 & - \\
\hline & Jun & 0.292 & - & 2.059 & - \\
\hline & Seasonal & \multicolumn{2}{|l|}{$\begin{array}{r}+0.375 \\
\end{array}$} & \multicolumn{2}{|l|}{$\begin{array}{r}+0.710 \\
\end{array}$} \\
\hline & & & & & \\
\hline \multirow{5}{*}{ 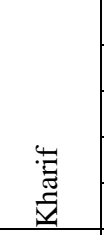 } & Jul & 0.564 & - & 2.398 & - \\
\hline & Aug & 0.562 & - & 2.127 & - \\
\hline & Sep & 0.471 & - & 1.190 & - \\
\hline & Oct & 0.802 & - & - & 0.326 \\
\hline & Average & \multicolumn{2}{|l|}{$+0.600-$} & \multicolumn{2}{|l|}{$\begin{array}{r}+1.347 \\
\end{array}$} \\
\hline \multirow[t]{2}{*}{ Season } & Month & \multicolumn{2}{|l|}{ TC } & \multicolumn{2}{|l|}{ PT } \\
\hline & & Over & Under & Over & Under \\
\hline \multirow{7}{*}{$\begin{array}{l}\overrightarrow{\tilde{*}} \\
\tilde{\tilde{\alpha}}\end{array}$} & Nov & 0.544 & - & 0.204 & - \\
\hline & Dec & 0.494 & - & 0.049 & - \\
\hline & Jan & 0.318 & - & - & 0.106 \\
\hline & Feb & 0.453 & - & - & 0.191 \\
\hline & Mar & 0.176 & - & - & 0.382 \\
\hline & \begin{tabular}{|l} 
Seasonal \\
\end{tabular} & \multicolumn{2}{|l|}{$\begin{array}{r}\mathbf{0 . 3 9 7} \\
\end{array}$} & \multicolumn{2}{|l|}{-0.085} \\
\hline & & & & & \\
\hline \multirow{5}{*}{ 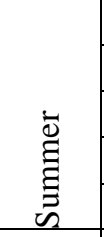 } & Apr & - & 0.233 & - & 0.993 \\
\hline & May & - & 0.853 & - & 1.183 \\
\hline & Jun & - & 0.967 & - & 0.270 \\
\hline & Seasonal & \multicolumn{2}{|l|}{-0.684} & \multicolumn{2}{|l|}{-0.815} \\
\hline & & & & & \\
\hline \multirow{5}{*}{$\begin{array}{l}\text { 志 } \\
\text { 志 } \\
\end{array}$} & Jul & - & 0.199 & 0.727 & - \\
\hline & Aug & 0.038 & - & 0.827 & - \\
\hline & Sep & 0.192 & - & 0.800 & - \\
\hline & Oct & 0.401 & - & 0.496 & - \\
\hline & Average & \multicolumn{2}{|l|}{+0.108} & \multicolumn{2}{|c|}{+0.713} \\
\hline
\end{tabular}

Note : the +ve sign in the seasonal over/under estimation row indicates the over estimation rate in $\mathrm{mm} /$ day and the - 
ve sing indicates the under estimation rate in $\mathrm{mm} /$ day

The performance and accuracy of FAO-PM method can never be debated in theoretical or practical applications, yet the comparative evaluation performed in this paper can be used as guideline for selection of alternative or less data dependent methods in case of non-availability of data. To facilitate the researchers, water managers or decision makers in selecting the best suitable method in case of less data availability (less parameters), the comparative evaluation of four most popular methods is summarized in Table 8. The decision maker can refer to this table with respect to data available in hand and/or accuracy required for particular ET estimation task.

Table 8: Applicability viz-a-viz expected error in $\mathrm{ET}_{0}$ estimation of all four methods

\begin{tabular}{|l|l|l|l|l|}
\hline \multirow{2}{*}{} & \multicolumn{4}{|l|}{ ET Estimation Methods } \\
\cline { 2 - 5 } & HS & TH & TC & PT \\
\hline Data Available & \multicolumn{4}{|l|}{ Applicability of method } \\
\hline T & $\checkmark$ & $\checkmark$ & $\times$ & $\times$ \\
\hline T+RH & $\checkmark^{*}$ & $\checkmark^{*}$ & $\checkmark$ & $\times$ \\
\hline T+RH+Rad/SS & $\checkmark^{*}$ & $\checkmark^{*}$ & $\checkmark^{*}$ & $\checkmark$ \\
\hline T+RH+Rad/SS+W & $\checkmark^{*}$ & $\checkmark^{*}$ & $\checkmark^{*}$ & $\checkmark^{*}$ \\
\hline
\end{tabular}

\begin{tabular}{|l|l|l|l|l|}
\hline Time Period & \multicolumn{4}{|l|}{$\begin{array}{l}\text { Expected error in } \text { ET }_{\boldsymbol{0}} \text { estimation } \\
(\boldsymbol{R M S E}) \text { [mm/day] }\end{array}$} \\
\hline Monthly Basis & 0.704 & 1.424 & 0.562 & 0.724 \\
\hline Rabi Season & 0.794 & 1.106 & 0.469 & 0.287 \\
\hline Kharif Season & 0.608 & 1.708 & 0.277 & 0.721 \\
\hline Summer Season & 0.688 & 1.420 & 0.904 & 1.105 \\
\hline \multicolumn{5}{|c|}{ estimation } \\
\hline Time Period & $\begin{array}{l}\text { Over/Under } \\
\text { [mm/day] }\end{array}$ \\
\hline Monthly Basis & +0.195 & -1.338 & -0.967 & -1.183 \\
& to & to & to & to \\
& +1.065 & +2.398 & +0.544 & +0.827 \\
\hline Rabi Season & +0.813 & -1.083 & +0.397 & -0.085 \\
\hline Kharif Season & +0.600 & +1.347 & +0.108 & +0.713 \\
\hline Summer Season & +0.375 & +0.710 & -0.684 & -0.815 \\
\hline
\end{tabular}

Note : 1) In data available section $T=$ Temperature data, $R H=$ Relative Humidity data, Rad= Radiation data, $S S=$ Sunshine Hours data, W= Average Wind Velocity data

2) $\checkmark=$ method can be applied using this data, ${ }^{*}=$ some of the available parameters will not be used in this method, $\times$ = method cannot be applied due to insufficient data.

3) The +ve sign in the over/under estimation rows indicates the over estimation rate in $\mathrm{mm} /$ day and the -ve sing indicates the under estimation rate in $\mathrm{mm} /$ day

\section{SUMMARY AND CONCLUSIONS}

Five methods (FAO-56 Penman-Monteith, Priestley-Taylor, Turc, Hargreaves and Thornthwaite) have been applied to estimate reference evapotranspiration using weather data of meteorological observatory at GBPUA\&T, Pantnagar. As per the recommendations of FAO expert consultation Panel [28] the $\mathrm{ET}_{0}$ estimated using FAO-56 Penman-Monteith method was taken as standard $\mathrm{ET}_{0}$ for comparative evaluation of other four methods.

The regression and error analysis of these methods on monthly time scale shows that TC method performance as best among all the methods on monthly basis with lowest error $(\mathrm{RMSE}=0.562, \mathrm{AAD}=0.448 \& \mathrm{ARE}=0.137)$ and high coefficient of determination $\left(\mathrm{R}^{2}=0.794\right)$. The total annual $\mathrm{ET}_{0}$ values estimated using $\mathrm{TC}$ method are closest to standard annual $\mathrm{ET}_{0}$ values. While HS method was found to be second to TC method on monthly time scale with low RMSE (0.704) highest coefficient of determination $\left(\mathrm{R}^{2}=\right.$ 0.889).

On seasonal scale it was observed that the coefficient of determination $\left(\mathrm{R}^{2}\right)$ do not give the actual representation of accuracy of method with respect to closeness of $\mathrm{ET}_{0}$ estimate with standard $\mathrm{ET}_{0}$. Hence performance evaluation of each of the method was done using error and under/over predication rate as criteria. In Rabi season PT method performed better than all other methods with minimum RMSE (0.287) and minimum over/under predication rate with reference to standard $\mathrm{ET}_{0}(-0.085)$. Total seasonal $\mathrm{ET}_{0}$ in Rabi season estimated using PT is almost equal to Standard $\mathrm{ET}_{0}$. On the other hand less data requiring TC method holds second rank with approximately $0.5 \mathrm{~mm} /$ day root mean square error. Hence the analysis indicates that, in case of non-availability wind and radiation data TC method can be applied using temperature, humidity and sunshine hours data to derive fairly accurate results of $\mathrm{ET}_{0}$.

In Kharif season TC method performs best among all other methods with lowest errors (RMSE $=0.277$, ARE $=0.172$ ), lowest deviation in standard and estimated $\mathrm{ET}_{0}$ (AAD $=0.226$ ) and lowest seasonal over/under $\mathrm{ET}_{0}$ estimation rate (0.108). In summer season all the methods performed poorly compared to other two seasons, but HS performed well among all other methods with lowest errors (RMSE $=0.688$, $\mathrm{ARE}=0.097$ ), lowest deviation from standard $\mathrm{ET}_{0}$ values $(\mathrm{AAD}=0.522)$. It was observed that the seasonal rate of over/under predication of all other methods was high in summer season, however the seasonal over/under predication rate of HS method is minimum in summer not only in compression to other method but also in compression to it's own rate in other seasons. This may be because of basic physical and dynamical nature of this method.

The comparative performance evaluation of these four ET estimation techniques done in present paper is site specific and the results may vary site to site, but this form of study will help decision maker to select the best possible ET estimation technique with respect to data/cost constraints or accuracy constrains. Similarly kind of studies on larger scale for each agro-climate zone will enable compilation of standard document for selection of best possible ET estimation of technique in accordance with data/fund availability. 


\section{ACKNOWLEDGEMENTS}

Authors are grateful to The Joint Director, Crop Research Centre, G. B. Pant University of Agriculture and Technology, Pantnagar for providing relevant data.

\section{REFERENCES}

[1]. Allen, R. G., Pereira, L. S., Raes, D. and Smith, M. (1998). Crop Evapotranspiration. Guidelines for Computing Crop Water Requirements. Irrigation and Drainage Paper No. 56, Food and Agricultural Organization (FAO) Roma.

[2]. Amatya, D. M., Skaggs, R. W. and Gregory, J. D. (1995). Comparison of methods for estimating potential evapotranspiration. Journal of Irrigation and Drainage Engineering, 121(6), 427-435.

[3].Azhar, A. H. and Perera, B. J. C. (2011) Evaluation of reference evapotranspiration estimation methods under Southeast Australian conditions. Journal of Irrigation and Drainage Engineering 137, 268-279.

[4]. Benli, B., Bruggeman, A., Oweis, T. and Ustun, H. (2010) Performance of Penman-Montheith FAO56 in a Semi-Arid highland Environment. Journal of Irrigation and Drainage Engineering, 136 (11), 757-765.

[5]. Clothier, B. E., Kerr, J. P., Talbot, J. S. and Scotter, D. R. (1982). Measured and estimated evapotranspiration from well-watered crops. N. Z. J. Agricultural Research, 25, 301307.

[6]. Colin C., A., Windmeijer, F. A.G., Gramajo, H., Cane, D. E. and Khosla, C. (1997). An R-squared measure of goodness of fit for some common nonlinear regression models. Journal of Econometrics, 77 (2), 1790-1792

[7]. Doorenbos, J. and Pruitt, W. O. (1977). Guidelines for Predicting Crop Water Requirements. Irrigation and Drainage Paper No. 24, Food and Agricultural Organization (FAO), Rome.

[8]. Fisher, J. B., DeBiase, T. A., Qi, Y., Xu, M. and Goldstein, M. A. (2005). Evapotranspiration models compared on a Sierra Nevada forest ecosystem. Environmental Modelling and Software, 20, 783-796.

[9]. Gavilán, P., Lorite, I. J., Tornero, S. and Berengena, J. (2006). Regional calibration of HAG equation for estimating reference ET in a semiarid environment. Agricultural Water Management, 81, 257-281.

[10]. Hargreaves, G. H. and Allen, R. G. (2003). History and evaluation of Hargreaves evapotranspiration equation. Journal of Irrigation and Drainage Engineering, 129(1), 5363.

[11]. Hargreaves, G. H. and Samani, Z. A. (1985). Reference crop evapotranspiration from temperature. Applied Engineering in Agriculture, 1(2), 96.

[12]. Irmak, S., Allen, R. G. and Whitty, E. B. (2003). "Daily grass and alfalfa-reference evapotranspiration estimates and alfalfa-to-grass evapotranspiration ratios in
Florida. Journal of Irrigation and Drainage Engineering, 129 (5), 360-370.

[13]. Itenfisu, D., Elliott, R. L., Allen, R. G. and Walter, I. A. (2003). Comparison of Reference Evapotranspiration Calculations as a Part of the ASCE Standardization Effort. Journal of Irrigation and Drainage Engineering, 129(6):440448.

[14]. Jensen, M. E., Burman, R .D. and Allen, R. G. (ed). (1990). Evapotranspiration and Irrigation Water Requirements. ASCE Manuals and Report on Engineering Practices No. 70, New York, 332-333.

[15]. Kashyap, P. S. and Panda, R. K. (2001). Evaluation of evapotranspiration estimation methods and development of crop-coefficients for potato crop in sub-humid region. Agricultural Water Management, 50, 9-25.

[16]. Kumar, K. K., Kumar, K. R. and Rakhecha, P. R. (1987). Comparison of Penman and Thornthwaite methods of estimating potential evapotranspiration for Indian conditions. Theoretical and Applied Climatology, 38, 140146.

[17]. Lopez-Urrea, R., Martin de Santa Olalla, F., Fabeiro, C. and Moratalla, A. (2006) Testing evapotranspiration equations using lysimeter observations in a semiarid climate. Agricultural Water Management, 85, 15-26.

[18]. Mall, R. K. and Gupta, B. R. D. (2002). Comparison of evapotranspiration models. Mausam, 53(2), 119-126.

[19]. Michalapoulou, H. and Papaioannou, G. (1991). Reference crop evapotranspiration over Greece. Agricultural Water Management, 20, 209-221.

[20]. Mohan, S. (1991). Intercomparison of evapotranspiration estimates. Hydrological Sciences Journal, 36 (5), 447-460.

[21]. Nandagiri, L. and Kovoor, G. M. (2006). Performance Evaluation of Reference Evapotranspiration Equations across a Range of Indian Climates. Journal of Irrigation and Drainage Engineering, 132(3 ), 238-249.

[22]. Ngongondo, C., Xu, C.Y., Tallaksen, L. M. and Alemaw, B. (2013). Evaluation of the FAO PenmanMontheith, Priestley-Taylor and Hargreaves models for estimating reference evapotranspiration in southern Malawi. Hydrology Research, In Press.,doi. 10.2166/nh2012.224

[23]. Parmele, L. H. (1972). Errors in output of hydrologic models due to errors in input of potential evapotranspiration. Water Resources Research, 8, 348-359.

[24]. Parmele, L. H. and McGuinness, J. L. (1974). Comparisons of measured and estimated daily potential evapotranspiration in a humid region. Journal of Hydrology, 22, 239-251.

[25]. Priestley, C. H. B. and Taylor, R. J. (1972). On the assessment of surface heat flux and evaporation using largescale parameters. Monthly Weather Review, 100(2), 81-92. 
[26]. Singh, V. P. and Xu, C.-Y. (1997a). Evaluation and generalization of 13 equations for determining free water evaporation. Hydrological Processes, 11, 311-323.

[27]. Smajstrla, A. G., Clark, G. A. and Shih, S. F. (1984). Comparison of potential evapotranspiration calculation methods in a humid region. Paper No. 8420/0, 1984 ASAE Summer Meeting, Am. Soc. Agric. Engrs. (ASAE), St. Joseph, Mich.

[28]. Smith, M, Allen, R. G., Monteith, J. L., Pereira, L. S., Perrier, A. and Prutti, W. O. (1992). Report on the expert consultation on procedure for revision of FAO guidelines for predicting of crop water requirements. Land and Water Development Division, United Nations Food and Agriculture Services, Rome, Italy.

[29]. Subramaniam, A. R. and Rao, A. S. (1985). "Prediction of ET of some crops under semi-arid and dry sub-humid climates of Maharashtra." Mausam, 36(1), 6770 .

[30]. Suleiman, A. A. and Hoogenboom, G. (2010). Comparison of Priestley-Taylor and FAO-56 PenmanMonteith for daily reference evapotranspiration estimation in Georgia. Journal of Irrigation and Drainage Engineering 133,175 .

[31]. Sumner, D. M., and Jacobs, J. M. (2005). Utility of Penman-Monteith, Priestley-Taylor, reference evapotranspiration, and pan evaporation methods to estimate pasture evapotranspiration. Journal of Hydrology, 308, 81104.

[32]. Thornthwaite, C. W. (1948). An approach toward a rational classification of climate. The Geographical Review, 38(1), 55-94.

[33]. Turc, L. (1961). Estimation of irrigation water requirements, potential evapotranspiration: A simple climatic formula evolved up to date. Annals of Agronomy. (12),13-14.

[34]. Tyagi, N. K., Sharma, D. K. and Luthra, S. K. (2003). Determination of evapotranspiration for maize and berseem clover. Irrigation Science, 21, 173-181.

[35]. Ventura, F., D., Duce, S. P. and Snyder, R.L. (1999). An evaluation of common evapotranspiration equations. Irrigation Science, 18:163-170.

[36]. Walter, I. A., Allen, R. G. ., Elliott, R., Jensen, M. E., Itenfisu, D., Mecham, B., Howell, T. A., Snyder, R., Brown, P., Eching, S., Spofford, T., Hattendorf, M., Cuenca, R. H., Wright, J. L. and Martin, D. (2000). ASCE's Standardized Reference Evapotranspiration Equation. Proc., $4{ }^{\text {th }}$ National Irrig. Symp., ASAE, Phoenix, AZ.

[37]. Xu, C. Y. and Singh, V. P. (2002). "Cross comparison of empirical equations for calculating potential evapotranspiration with data from Switzerland." Water Resources Management, 16, 197-219.

[38]. Xu, C.-Y. and Singh, V. P. (2000). Evaluation and generalisation of radiation-based equations for calculating evaporation. Hydrological Processes 14, 339-349.
[39]. Xu, C.-Y. and Singh, V. P. (2001). Evaluation and generalization of temperature-based methods for calculating evaporation. Hydrological Processes 15, 305-319.

[40]. Xu, C.-Y. and Singh, V. P. (2002). Cross comparison of empirical equations for calculating potential evapotranspiration with data from Switzerland. Water Resources Management, 16, 197-219. 